\title{
Pharmaceutical crops have a mixed outlook in California
}

\author{
by Michelle Marvier
}

Crops are being genetically engineered to produce a wide variety of drugs, vaccines and other pharmaceutical proteins. Although these crops may open the door to less expensive and more-readily available drugs, there is concern regarding the potential for contamination of human food and livestock feed, as well as environmental harm. The outlook for the production of pharmaceutical crops in California currently appears mixed. To date, 18 federal permits for field trials involving pharmaceutical or industrial proteins have been approved in California. However, the state's farming community and general public have thus far rejected pharmaceutical crop production, and a handful of local governments have recently banned the cultivation of genetically modified crops, including pharmaceutical crops. In light of the many pros and cons, three major approaches - the precautionary approach, risk analysis and cost-benefit analysis - could be used to move the debate about pharmaceutical crops forward.

- $v$ ven science fiction writers did not dream that we would someday use maize fields to produce insulin, or rice paddies to grow anticoagulants. Today, however, crops are being turned into factories producing not just food, but drugs, vaccines, enzymes and antibodies. The first step in using crops to produce pharmaceutically active proteins is the synthesis or isolation of genes that code pharmaceutical proteins, followed by the transfer of those genes into the DNA of crop plants. These transferred genes, or "transgenes," can potentially come from a different plant species, an

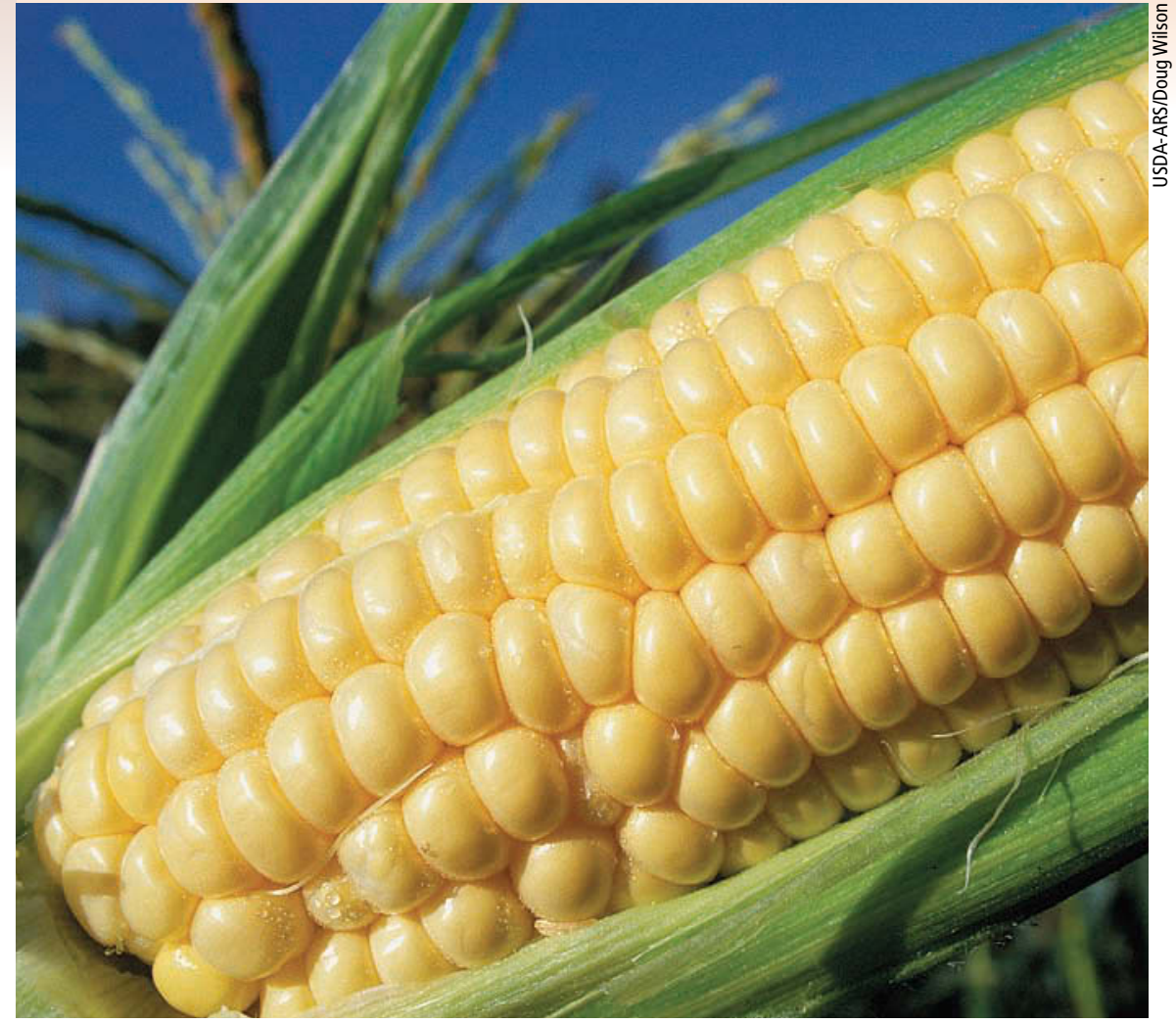

Proponents of crops genetically engineered to express pharmaceutical proteins believe that these crops could increase the availability of medicines and vaccines, and lower costs. To date, about two-thirds of pharmaceutical field-trials in the United States have involved maize, a wind-pollinated species (conventional corn is shown).

animal (often a human) or a bacterium. The genetically modified crops are then cultivated and harvested.

In most cases, the crop-produced pharmaceutical protein is extracted, purified and possibly modified further before it is administered to humans or livestock. In some instances, however, crops are being engineered so that a vaccine can be delivered through the direct consumption of leaves, fruits or other plant parts, without the cost and inconvenience of extracting the proteins and delivering them via pills or injections (Sala et al. 2003).

\section{Benefits of pharmaceutical crops}

Scientists are drawn to the genetic engineering of crops as a means of quickly producing large quantities of drugs and vaccines, with the hope that this technology can reduce costs and increase the availability of muchneeded pharmaceuticals (Fischer et al. 2004; Giddings et al. 2000; Horn et al. 2004; Ma et al. 2003; Ma, Barros et al. 2005). The potential products of transgenic plants include blood thinners, hemoglobin, insulin, growth hormones, cancer treatments and contraceptives. Products already in the pipeline include plant-produced vaccines for hepatitis- $B$, cholera, rabies, $\mathrm{HIV}$, malaria and influenza. One company is developing genetically modified maize (corn) to produce lipase, a digestive enzyme used to treat patients with cystic fibrosis. Arthritis and other autoimmune diseases are also targets for plant-produced vaccines (Sala et al. 2003). Researchers have focused on maize, bananas, tomatoes, carrots and lettuce as possible oral-delivery mechanisms for such vaccines because these foods can be eaten raw, thereby avoiding the protein denaturing that typically occurs during cooking (Sala et al. 2003). Producing vaccines in food plants would eliminate the need for refrigeration, which limits the usefulness 
Human error occurs and, frankly, is unavoidable.
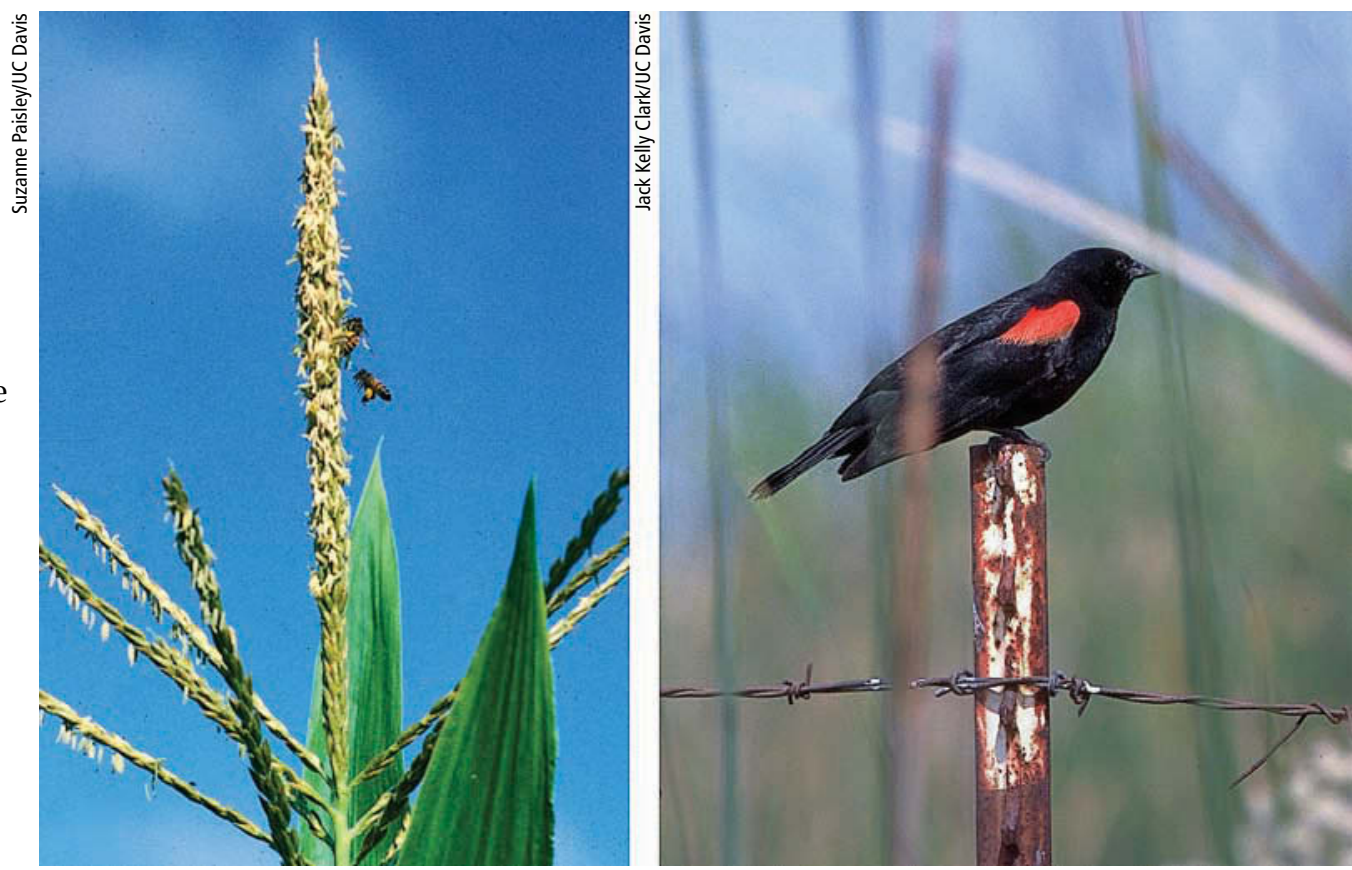

Whenever pharmaceutical-producing crops are grown outside, it is virtually inevitable that birds, insects and other wildlife will eat them, resulting in unknown risks to the animals, and that the pollen and seeds will be transported offsite. Left, bees on a corn stalk. Right, a red-winged blackbird.

tures of genetically modified cells, these cells were kept under strict confinement in laboratories. The production of pharmaceutical proteins in maize or rice, on the other hand, will typically be done in the field where it will be impossible to completely contain the crops, transgenes and pharmaceutical proteins (Ellstrand 2006). Production of these crops in contained greenhouses or underground caves has been proposed as a potential, albeit far less cost-effective, solution.

Contamination of food and feed. In 2002, 130 acres of pharmaceutical maize were cultivated in the United States in field trials. Two-thirds of all pharmaceutical plantings in the United States are maize, but soybeans, rice, potatoes, alfalfa, wheat, tobacco and other crops are also being used. The primary concern is that the public might someday find unwanted medicines in their food or in livestock feed (Elbehri 2005; Kirk et al. 2005; Mascia and Flavell 2004; Peterson and Arntzen 2004).

Food can be contaminated when transgenes are not contained, or if plant products intended only for medicinal uses accidentally comingle with those headed for our dinner tables. Transgenes can escape when pollen from pharmaceutical crops drifts into and fertilizes fields of nonpharma- ceutical crops. Due to the energetic costs that producing pharmaceutical proteins likely entails, it is unlikely that transgenes coding for pharmaceutical products would persist for very long within the recipient gene pool. However, even transient transgene flow could cause problems. For example, if transgenic pollen fertilizes seed kernels on a nontransgenic maize plant, the kernels could produce and contain the pharmaceutical protein. Alternatively, if seeds are left behind in the soil following harvest, "volunteer" pharmaceutical plants could establish themselves in subsequent growing seasons, possibly in mixture with nonpharmaceutical crops. Because some pharmaceutical compounds are effective in very low concentrations, even low-level contamination may pose risks.

Transgene escape from food crops. Although pharmaceutical crops are still rarely produced and only under tightly regulated conditions, there already has been one revealing case of transgene escape involving field trials of pharmaceutical maize in Nebraska and Iowa. In November 2002, the U.S. Department of Agriculture (USDA) discovered that ProdiGene had failed to comply with federal regulations in two of its field trials, which involved maize genetically modified to produce a vaccine that pre- 


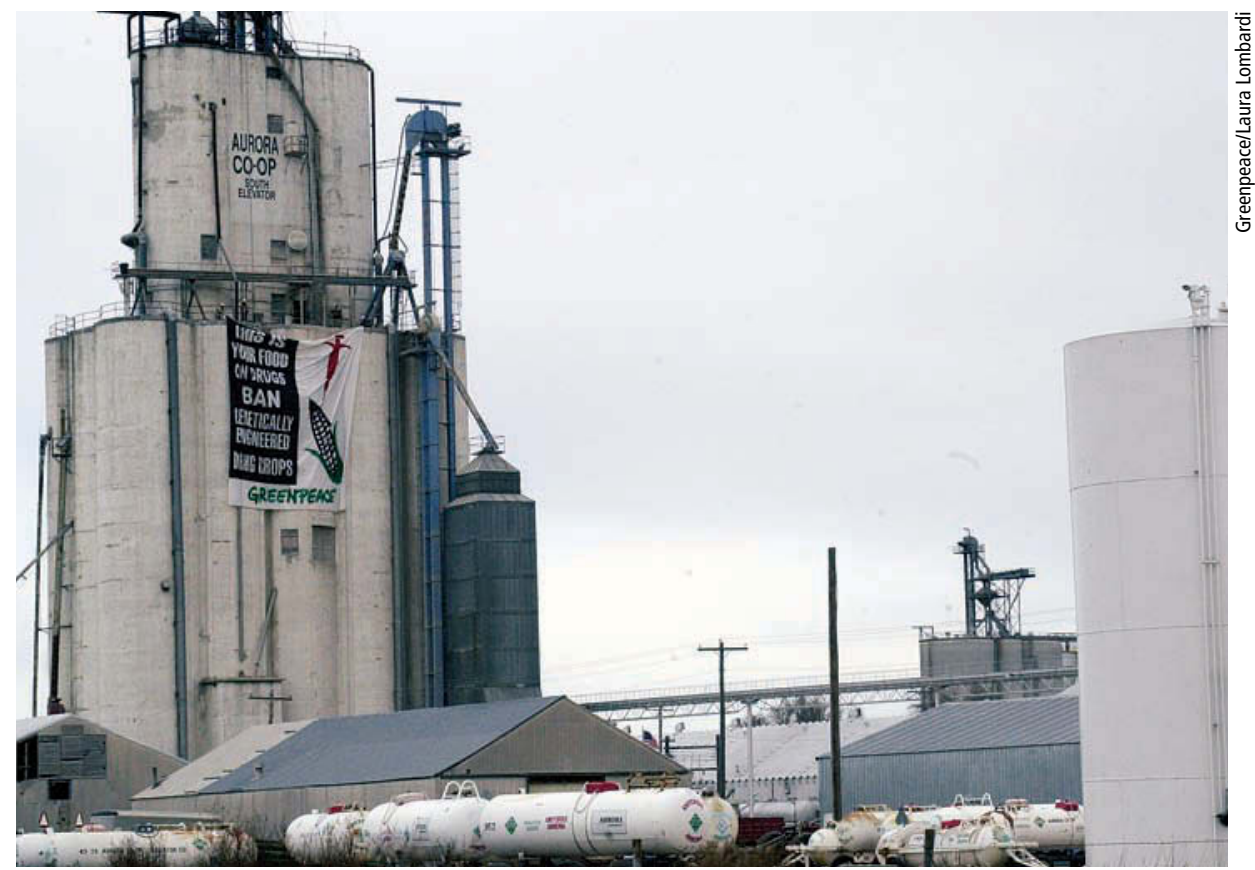

In 2002, field trials of pharmaceutical maize went awry when the producer failed to destroy volunteer maize during the subsequent growing season. As a result, 500,000 bushels of harvested soybeans were destroyed in Aurora, Nebraska. Greenpeace activists hung a banner on the silo.

vents diarrhea in pigs. In both locations, ProdiGene failed to destroy volunteer maize plants in the subsequent growing season. In Nebraska, the mistake was not discovered until after the volunteer maize had been shredded and mixed among soybeans that had been subsequently planted at the site. This meant that 500,000 bushels of soybeans had to be destroyed. In Iowa, there was no mixing with soybeans, but 155 acres of maize surrounding the pharmaceuticalcrop test site were destroyed because of possible contamination via pollen from volunteer plants. ProdiGene was fined $\$ 300,000$ for these violations, and also paid \$2.7 million in damages and cleanup costs.

A half-dozen more examples of human error involving other, nonpharmaceutical-producing types of genetically modified crops were reviewed by Marvier and Van Acker (2005). Since the publication of that paper, Syngenta admitted to accidentally distributing the seeds of an unapproved variety of genetically modified insect resistant Bt10 maize over a 4-year period (Macilwain 2005), and traces of Bayer's Liberty Link 601 herbicide-resistant rice have been detected in both U.S. and European long-grain food rice, even though the variety was never approved or marketed (Vogel 2006). The lesson from these events is that human error occurs and, frankly, is unavoidable.

\section{Food versus nonfood crops}

The possible escape of pharmaceutical products from engineered crops into the food supply is of concern to the promoters of genetic engineering, as well as environmentalists. For example, an editorial in the journal Nature Biotechnology offered two suggestions that could help industry to avoid foreseeable problems (Editors of Nature Biotechnology 2004). First, engineered crops could be geographically isolated to reduce the chances of contamination in the general food supply. For example, pharmaceutical crops might be cultivated on islands where the food crop is otherwise absent. Second, the editors recommended that food crops should not be used to produce pharmaceutical proteins, and that nonfood crop alternatives such as tobacco might be a wiser choice. The National Research Council (2004) concurred, stating, "Alternative nonfood host organisms should be sought for genes that code for transgenic products that need to be kept out of the food supply."

Despite the National Research Council's recommendations, many biotechnology firms are nonetheless using food grains as platforms for pharmaceutical production. As of 2003, over three-quarters of field trials conducted to produce pharmaceutical or industrial proteins (including fibers, plastics and enzymes) had involved maize, a wind-pollinated species (Union of Concerned Scientists 2003). Grain crops are favored because protein yields from the large seeds of maize, rice and barley are typically much higher than those obtained from leaves and other vegetative parts. In addition, pharmaceutical proteins can remain stable in dried grain for several years, compared to the much-reduced stability of these same proteins in leaf tissue. Moreover, maize is generally recognized as safe for ingestion by the U.S. Food and Drug Administration (FDA) and therefore can be used as an inactive carrier, suitable for drug delivery.

Despite these advantages, warnings from critics may be having an effect. A growing number of companies are focusing on tobacco, or even mosses, algae and duckweed, as platforms for pharmaceutical production (Fischer et al. 2004). These plants, however, pose risks of their own that must be considered. Algae and duckweed, if cultivated, would have greater potential than highly domesticated crop species to escape from cultivation. 


\section{Additional routes of exposure}

Even if the production of pharmaceutical proteins was limited to nonfood crops, potential risks would remain. Pollen, fine particles of leaves that are crushed during harvest, and possibly even runoff water contaminated with proteins from decomposing plants, could expose people and wildlife that live on or near pharmaceuticalproducing fields to the transgenic material. Whenever production occurs outside, birds, insects and other wildlife can consume pharmaceutical crops, regardless of where they are grown or what species they are. Pharmaceutical crops may also affect soils and the community of soil-dwelling organisms.

Such impacts on wildlife and soils have received scarce attention from scientists and regulators, but surely will vary greatly by variety depending on the nature of the protein being produced. One possible strategy to avoid these problems would be to engineer proteins so that they do not become biologically active until after they are extracted and further processed in a laboratory.

\section{Regulatory responses}

Pharmaceutical crop varieties are not expected to be deregulated; rather, it is likely that they will only be produced in field trials as permitted under USDA regulatory oversight. Initially, field-trial applications for pharmaceutical crops were treated like those for any other regulated, genetically modified crop. However, the USDA recently published stricter requirements specifically designed for plants genetically engineered to produce pharmaceutical and industrial proteins (Federal Register 2003). These new requirements aim to reduce the risk of gene flow and the contamination of food and feed. Confinement measures now required for pharmaceutical crops include greater geographic isolation from other fields of the same species, buffer zones of bare soil around the field edge, scouting for and destroying volunteer plants in subsequent field seasons, and the dedication of equipment for use only on the trial fields.

There is a precedent for the successful segregation of crop varieties

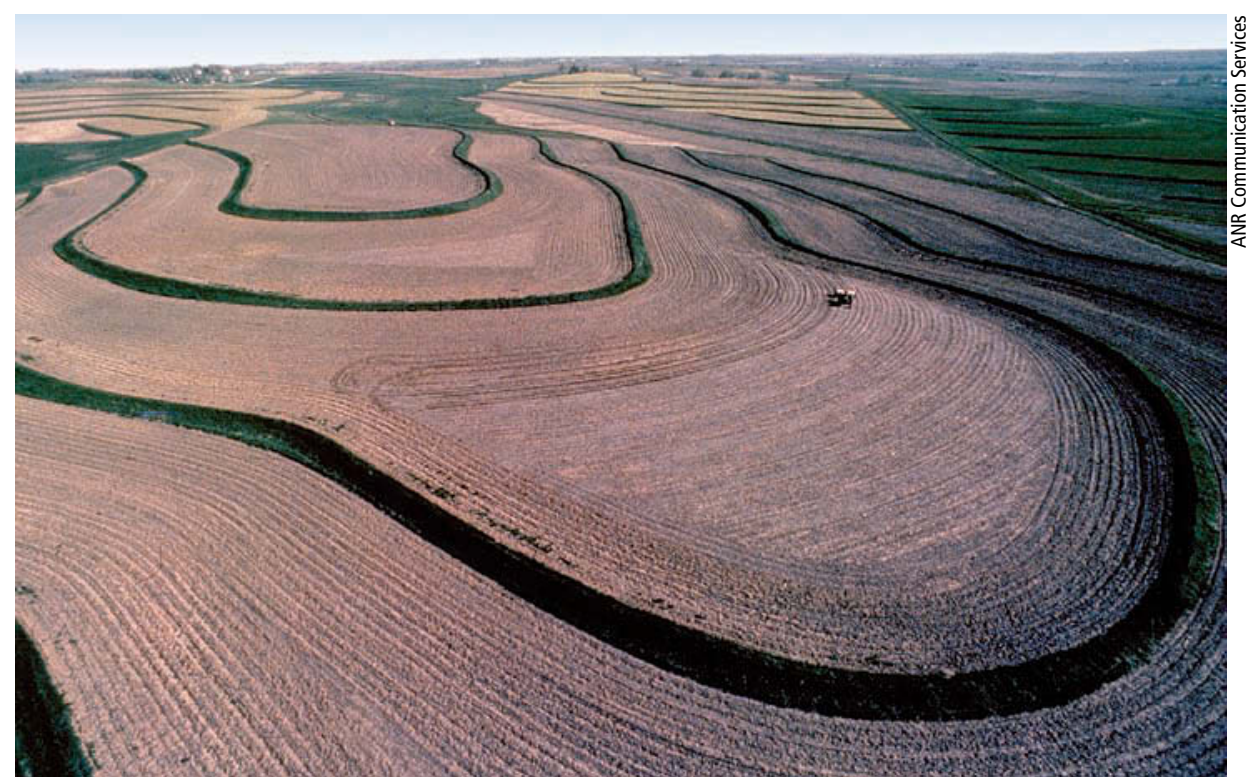

In California, rice farmers strongly opposed efforts to grow 120 acres of rice genetically engineered to produce proteins for two pediatric medicines, fearing that their exports to Asia would be jeopardized. Above, a California rice farm (not genetically engineered).

intended for use in food from those intended for industry. Rapeseed varieties containing high levels of erucic acid are segregated from those used to produce canola oil, which must contain less than $2 \%$ erucic acid (Ma, Chikwamba et al. 2005). Erucic acid is used to create lubricants, coatings and surfactants, but the regular consumption of large amounts of erucic acid has been linked to heart disease in animal studies. Producers of high-erucic-acid rapeseed must maintain a minimum 16.4-foot buffer zone around their fields and clearly label harvested products. In addition, erucic acid levels in canola oil are regularly monitored by various food inspection agencies.

Although this example demonstrates the potential for successful segregation, more-stringent protocols would be required to produce pharmaceutical proteins in food crops. In the case of erucic acid, a low level of cross contamination is acceptable (Bilsborrow et al. 1998), but for pharmaceutical compounds there is generally zero tolerance. Studies examining the potential for the coexistence of other types of genetically modified crops with nongenetically modified varieties demonstrate that contamination can be limited (for example, less than $0.9 \%$ ) but not entirely prevented (EuropaBio 2006). Moreover, in the rapeseed example, only one or two compounds must be monitored. In contrast, if maize is eventually used to produce some 50 or 100 different pharmaceutical compounds, the costs for systematic monitoring to ensure that none of these compounds contaminates maize intended for food or feed could be prohibitive.

In addition to rules governing how pharmaceutical crops are grown, USDA inspectors have publicly announced that field-test sites of such crops will each be inspected five times during the growing season and twice postharvest (Stewart and Knight 2005). However, based on an audit that included site visits to 91 field-test locations in 22 states, the USDA Office of the Inspector General found that this level of inspection was not consistently maintained. The audit report concluded that weaknesses in the regulatory oversight of genetically modified crop field-trials increase the chance that these crops will inadvertently persist in the environment (USDA 2005). Of additional concern, the audit found that, "At the conclusion of the field test, APHIS does not require permit holders to report on the final disposition of genetically modified pharmaceutical and industrial harvests. ... As a result, [the inspectors] found two large harvests of genetically modified pharmaceutical crops remaining in storage at the field-test sites for over a year without APHIS's knowledge or approval of the storage facility" (USDA 2005). Clearly, better adherence to monitoring requirements is needed to minimize the risk of a loss of containment.

Although the 2003 regulations set forth by USDA are an important step, the proposed rules make no attempt 
to protect wildlife (fencing or netting are not required), assess how pollen or fine particulate matter from the crop might affect humans, or test soils and groundwater for pharmaceutical residues. Also missing is any requirement that the pharmaceutical variety be readily identifiable. For example, several authors have suggested that pharmaceuticals could be produced in "identity-preserved varieties, such as white tomatoes or maize, which are easily identified by their pigmentation" (Ma et al. 2003).

No specific requirements were proposed for molecular solutions to contamination, presumably because these are not sufficiently developed yet. However, molecular strategies hold great promise for the improved containment of transgenes. Examples include the genetic modification of chloroplast DNA rather than nuclear DNA (for crop species in which pollen does not contain chloroplasts, transgenes would not move with pollen) (Daniell et al. 2002) and the inducible production of pharmaceuticals (for example, the pharmaceutical protein is activated by exposure to ethanol vapor) (Mascia and Flavell 2004). The tissue-specific expression of pharmaceutical proteins may also reduce or eliminate certain avenues of exposure (such as the possibility of exposure via pollen inhalation), and gene deletion technologies could potentially be used to remove transgenes from certain tissues (such as pollen) to reduce the possibility of transgene spread (Keenan and Stemmer 2002).

If transgenes could be contained, then regulations could be much more permissive about which traits are allowed in crop plants. On the other hand, if transgenes will inevitably escape and spread - despite our best intentions for containment - then we must be much more cautious about which traits are allowed to be developed in crop plants. Alternatively, the cultivation of crops engineered to produce particularly hazardous pharmaceutical proteins might be restricted to greenhouses or other enclosed facilities, such as caves. Although production in such facilities is feasible, it would likely be far more expensive than field production.

\section{Field-testing in California}

The USDA database of field-trial permits for plants expressing pharmaceutical and industrial proteins includes many entries for which the petitioning organization has used a claim of Confidential Business Information to withhold from the public any information regarding the transgene, its source or the traits that have been altered (USDA APHIS 2007). It is therefore difficult to know exactly how many field trials of pharmaceutical crops have been approved in California. However, the Union of Concerned Scientists (2007) estimates that 18 permits for field trials involving pharmaceutical or industrial proteins were approved in California, the earliest in 1996 and one as recently as 2006 (table 1). According to this analysis, California is tied with Kentucky for seventh among U.S. states and territories, after Nebraska with 41 approved permits, Hawaii with 40, Puerto Rico

TABLE 1. USDA-approved field-trial permits allowing the growth of crops genetically engineered to produce pharmaceutical or industrial proteins in California, 1996-2006

\begin{tabular}{|c|c|c|c|c|}
\hline $\begin{array}{l}\text { Engineered } \\
\text { crop }\end{array}$ & Applicant & $\begin{array}{l}\text { Issued/ } \\
\text { effective }\end{array}$ & $\begin{array}{c}\text { Source of } \\
\text { gene }^{*}\end{array}$ & Pharmaceutical or industrial protein \\
\hline \multirow{7}{*}{ Maize } & Dow & $6 / 2002$ & $\mathrm{CBIt}$ & CBI: Unidentified pharmaceutical protein \\
\hline & \multirow{2}{*}{ Monsanto } & $3 / 2001$ & $\mathrm{CBI}$ & $\begin{array}{l}\text { CBI: Unidentified transcriptional activator } \\
\text { (pharmaceutical) }\end{array}$ \\
\hline & & $3 / 2001$ & $\mathrm{CBI}$ & $\begin{array}{l}\text { CBI: Unidentified transcriptional activator } \\
\text { (pharmaceutical) }\end{array}$ \\
\hline & \multirow{4}{*}{ Pioneer } & $3 / 2000$ & Unclear $¥$ & $\begin{array}{l}\mathrm{CBI} \text { : Unidentified novel protein that may } \\
\text { have pharmaceutical or industrial uses }\end{array}$ \\
\hline & & $4 / 2001$ & Unclear & $\begin{array}{l}\mathrm{CBI} \text { : Unidentified novel protein that may } \\
\text { have pharmaceutical or industrial uses }\end{array}$ \\
\hline & & $4 / 2002$ & Unclear & $\begin{array}{l}\text { CBI: Unidentified industrial enzyme and } \\
\text { unidentified novel protein that may have } \\
\text { pharmaceutical or industrial uses }\end{array}$ \\
\hline & & $4 / 2004$ & Unclear & $\begin{array}{l}\mathrm{CBI} \text { : Unidentified novel protein that may } \\
\text { have pharmaceutical or industrial uses }\end{array}$ \\
\hline $\begin{array}{l}\text { Leaf } \\
\text { mustard }\end{array}$ & \multirow{2}{*}{$\begin{array}{l}\text { USDA } \\
\text { Agricultural } \\
\text { Research } \\
\text { Service }\end{array}$} & $3 / 2004$ & Unclear & CBI: Unidentified industrial enzyme \\
\hline $\mathrm{CBI}$ & & $3 / 2004$ & $\mathrm{CBI}$ & CBI: Unidentified industrial enzyme \\
\hline Rapeseed & Pioneer & 9/1996 & $\mathrm{CBI}$ & CBI: Unidentified pharmaceutical protein \\
\hline \multirow{7}{*}{ Rice } & \multirow{7}{*}{$\begin{array}{l}\text { Ventria } \\
\text { Bioscience } \\
\text { (formerly } \\
\text { Applied } \\
\text { Phytologics) }\end{array}$} & $3 / 1997$ & Humans & $\begin{array}{l}\text { Pharmaceutical proteins: Antithrombin and } \\
\text { serum albumin }\end{array}$ \\
\hline & & 2/1998 & Humans & $\begin{array}{l}\text { Pharmaceutical proteins: Antitrypsin, } \\
\text { antithrombin and serum albumin }\end{array}$ \\
\hline & & 2/1998 & $\mathrm{CBI}$ & CBI: Unidentified pharmaceutical protein \\
\hline & & $5 / 2000$ & $\mathrm{CBI}$ & $\begin{array}{l}\text { CBI: Unidentified pharmaceutical protein } \\
\text { and unidentified novel protein that may } \\
\text { have pharmaceutical or industrial uses }\end{array}$ \\
\hline & & $4 / 2001$ & Humans & $\begin{array}{l}\text { Pharmaceutical proteins: Antitrypsin, } \\
\text { lactoferrin and lysozyme }\end{array}$ \\
\hline & & $4 / 2003$ & Humans & $\begin{array}{l}\text { Pharmaceutical proteins: Lactoferrin } \\
\text { and lysozyme }\end{array}$ \\
\hline & & $5 / 2004$ & Humans & $\begin{array}{l}\text { Pharmaceutical proteins: Lactoferrin } \\
\text { and lysozyme }\end{array}$ \\
\hline Tobacco & $\begin{array}{l}\text { Planet } \\
\text { Biotechnology }\end{array}$ & $6 / 2006$ & $\begin{array}{l}\text { Mice, } \\
\text { rabbits, } \\
\text { CBI }\end{array}$ & $\begin{array}{l}\text { Antibodies to tooth decay and } \\
\text { common cold }\end{array}$ \\
\hline
\end{tabular}

* Refers specifically to the gene coding for the industrial or pharmaceutical protein.

$\dagger \mathrm{CBI}=$ Confidential Business Information.

‡ Source of gene coding for industrial and/or pharmaceutical protein(s) cannot be determined from publicly available information.

Source: Union of Concerned Scientists 2007. 
with 39, Wisconsin with 29, Iowa with 27 and Illinois with 19.

Pharmaceutical rice. The production of pharmaceutical proteins in transgenic crops is meeting with some resistance in California, as Ventria Bioscience recently discovered. Ventria had received federal permits to grow approximately 100 acres of pharmaceutical rice in California almost annually since 1997 (see table 1). However, the company's plans to expand its 2004 field trials to 120 acres of rice engineered with synthetic human genes were met with strong opposition from California rice farmers and environmentalists. Ventria's rice has been genetically engineered to produce lactoferrin and lysozyme, compounds used to treat severe diarrhea in infants. However, farmers were concerned that even low levels of contamination of their rice crops could threaten exports to Asia.

The California Rice Certification Act of 2000 gave the California Rice Commission the authority to devise protocols governing the cultivation of any new rice variety that requires segregation. Despite farmers' concerns, on March 29, 2004, the commission approved planting guidelines for Ventria's expanded plantings in a 6 to 5 vote, on the condition that the field trials be conducted in counties such as Orange and San Diego, remote from the state's ricegrowing regions. Due to the late timing of the commission's decision and the need to plant immediately, Ventria then asked the California Department of Food and Agriculture (CDFA) to issue an emergency permit for the proposed field trials. On April 9, 2004, CDFA decided not to approve Ventria's proposal because federal regulators at USDA had not yet completed their review of Ventria's permit application. California regulators essentially deferred to federal regulation, reasoning that federal oversight of the field-trial application is both necessary and sufficient. In 2005, Ventria attempted to move its field trials to Missouri, where it met similar resistance from major rice purchasers.

Local bans. Although California regulators may be happy to defer to USDA judgment when it comes to genetically modified crops, the public and local communities are not always so accommodating. Several counties have considered banning genetically modified

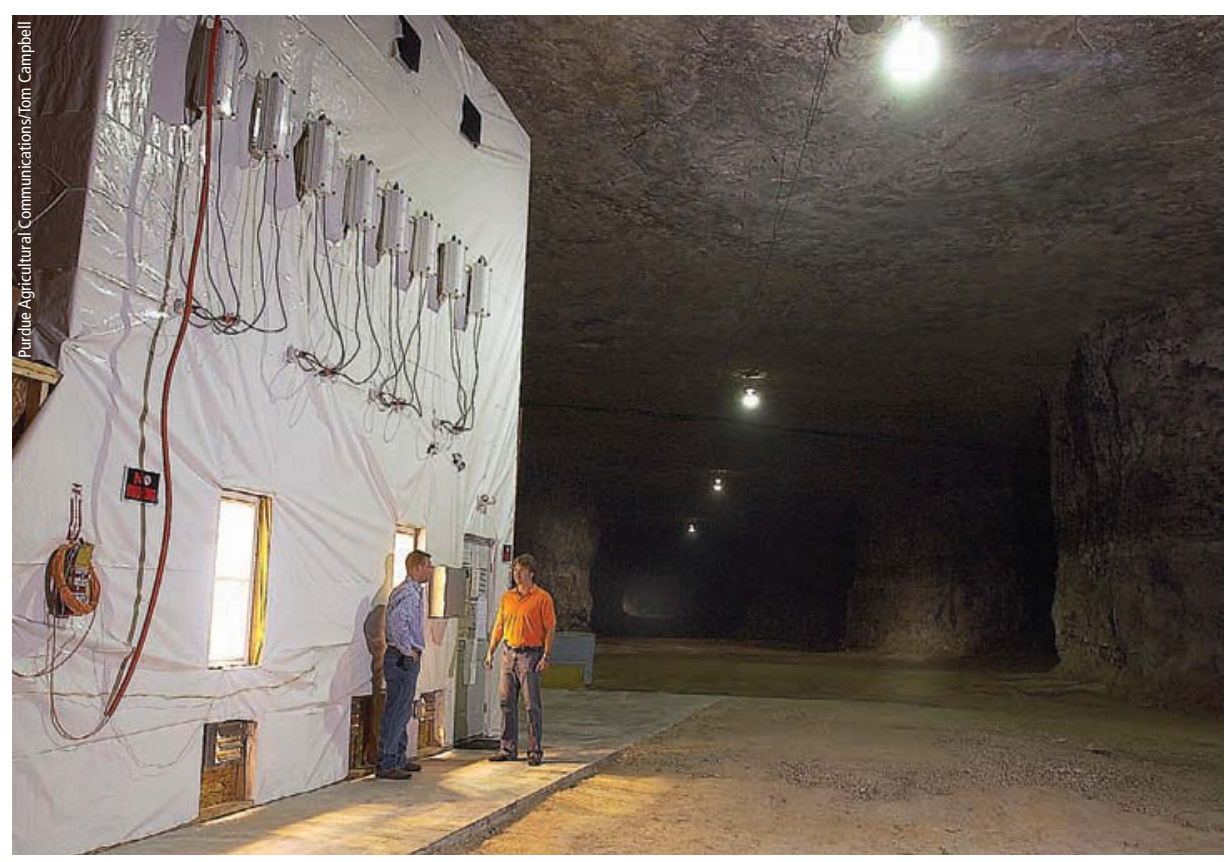

In an abandoned Indiana mine, Controlled Pharming Ventures is working with Purdue University researchers to develop techniques for growing pharmaceutical crops underground, in order to limit risks.

crops outright, and in some cases bans have indeed been implemented. Bans on all genetically modified plants are in effect in four counties: Mendocino (Measure H, passed by voters in March 2004), Trinity (passed by the county board of supervisors in August 2004), Marin (Measure B, passed by voters in November 2004) and Santa Cruz (unanimously passed by the county board of supervisors in June 2006). In contrast, voters rejected initiatives to ban genetically modified crops in four counties: Humboldt, San Luis Obispo and Butte in 2004, and Sonoma in 2005. Supervisors in several other California counties, including Fresno, Kern and Kings, have passed resolutions supporting the use of genetically modified crops.

The political future of local measures, either for or against genetically engineered crops, was recently challenged by Senate Bill 1056, which would have prohibited California counties, towns and cities from passing any local regulation of seeds and nursery plants. However, in September 2006, this bill failed to make it out of committee and died with the close of the legislative year. The failure of this bill leaves open the possibility of additional local restrictions on genetically modified crops in the future.

Economic considerations. In the end, economic concerns regarding the containment of food crops may outweigh concerns for the environment or even food safety. The contamination of U.S.produced rice with the unapproved Liberty Link 601 (herbicide-resistant) variety has had an enormous economic impact on U.S. rice growers. U.S. exporters of long-grain rice lost about $\$ 150$ million because genetically modified rice is banned throughout most of the European Union, a major importer of U.S. long-grain rice. Even greater economic losses would likely occur if a crop were found to be contaminated with a pharmaceutical protein. Whether pharmaceutical-producing crops will be accepted in California will likely depend on the economic value of other markets that might be placed at risk. A proposal to produce pharmaceutical rice within a major rice-producing area such as the Sacramento Valley is unlikely to be welcomed. However, a proposal to grow that same pharmaceutical rice in an area with very little other rice production may be acceptable.

\section{Evaluating risks and benefits}

All forms of agriculture entail some risks to the environment. Whenever food is grown, some species lose their habitat and some may be poisoned, trapped or shot; species extinctions are also possible. Pharmaceutical crops entail all of these same risks plus additional ones - the contamination of food and feed being the most serious. There 
regarding the production of pharmaceutical proteins in crop plants could be that the distribution of benefits (primarily to corporations) does not match the distribution of risks (primarily falling upon the general public).

Because biotech and pharmaceutical companies are the primary economic beneficiaries, the key questions for a cost-benefit approach applied to pharmaceutical crop production are whether the economic rewards outweigh the potential risks of unwanted pharmaceutical exposure, and whether the distribution of the costs and benefits is equitable and fair (Elbehri 2005). If economic profits are reinvested into the research and development of new drugs, then additional benefits for human and animal health may be achieved. In addition, drug prices might be reduced if it becomes inexpensive to manufacture drugs in large quantities. However, because most pharmaceutical crops are designed to produce patented pharmaceutical compounds, there would typically be little competition to drive prices lower. Furthermore,

\section{References}

Bilsborrow PE, Evans EJ, Bowman J, et al. 1998. Contamination of edible double-low oilseed rape crops via pollen transfer from high erucic cultivars. J Sci Food Agric 76:17-22.

Conko G. 2003. Safety, risk and the precautionary principle: Rethinking precautionary approaches to the regulation of transgenic plants. Transgen Res 12:639-47.

Daniell H, Khan MS, Allison L. 2002. Milestones in chloroplast genetic engineering: An environmentally friendly era in biotechnology. Trend Plant Sci 7:84-91.

Editors of Nature Biotechnology. 2004. Drugs in crops - the unpalatable truth. Nat Biotechnol 22:133.

Elbehri A. 2005. Biopharming and the food system: Examining the potential benefits and risks. AgBioForum 8:18-25.

Ellstrand NC. 2006. When crop transgenes wander in California, should we worry? Cal Ag 60(3):116-25

EuropaBio. 2006. Understanding coexistence: Science, principles and practical experience. ABE/EuropaBio. www.europa-bio.be/documents/040406/

Understanding\%20Coexistence\%20Fact\%20File.pdf.

Federal Register. 2003. Field testing of plants engineered to produce pharmaceutical and industrial compounds. Fed Reg 68:11337-40.

Fischer R, Stoger E, Schillberg S, et al. 2004. Plantbased production of biopharmaceuticals. Curr Opin Plant Biol 7:152-8.

Giddings G, Allison G, Brooks D, et al. 2000. Transgenic plants as factories for biopharmaceuticals. Nat Biotechnol 18:1151-5.

Horn ME, Woodward SL, Howard JA. 2004. Plant molecular farming: Systems and products. Plant Cell Rep 22:711-20.

Keenan RJ, Stemmer WPC. 2002. Nontransgenic crops from transgenic plants. Nat Biotechnol 20:215-6. the research and development of pharmaceutical crops will likely remain very expensive.

Other potential benefits are possibly increased income for farmers and higher tax revenues (Wisner 2005). There is much hope that pharmaceutical crops will improve farmer incomes, but these benefits are unlikely in a global market where the production of pharmaceutical proteins in genetically modified crops could be undertaken in whichever nation has the lowest production costs and weakest regulatory restrictions (Wisner 2005). Another important issue for farmers concerns liability for contamination incidents. In the only precedent to date, ProdiGene was held accountable for its mistakes. Communities or regulatory agencies considering allowing the production of pharmaceutical crops will want assurances regarding who pays for any damages.

\section{A promising new technology?}

Like many new technologies, the genetic engineering of crops to produce pharmaceutical products has great prom-

Kirk DD, McIntosh K, Walmsley AM, et al. 2005 Risk analysis for plant-made vaccines. Transgen Res 14:449-62.

Ma JK-C, Barros E, Bock R, et al. 2005. Molecular farming for new drugs and vaccines. EMBO Rep 6:593-9.

Ma JK-C, Chikwamba R, Sparrow P, et al. 2005. Plant-derived pharmaceuticals - the road forward. Trend Plant Sci 10:580-5.

Ma JK-C, Drake PMW, Christou P. 2003. The production of recombinant pharmaceutical proteins in plants. Nat Rev Genet 4:794-805.

Macilwain C. 2005. US launches probe into sales of unapproved transgenic corn. Nature 434:423.

Marvier M, Van Acker R. 2005. Can crop transgenes be kept on a leash? Front Ecol Environ 3:99-106.

Mascia PN, Flavell RB. 2004. Safe and acceptable strategies for producing foreign molecules in plants. Curr Opin Plant Biol 7:189-95.

National Research Council. 2004. Biological Confinement of Genetically Engineered Organisms. Washington, DC: Nat Acad Pr. 284 p.

O'Brien M. 2000. Making Better Environmental Decisions: An Alternative to Risk Assessment. Cambridge, MA: MIT Pr. $352 \mathrm{p}$

Peterson RKD, Arntzen CJ. 2004. On risk and plantbased biopharmaceuticals. Trend Biotechnol 22:64-6.

Raskin I, Ribnicky DM, Komarnytsky S, et al. 2002. Plants and human health in the twenty-first century. Trend Biotechnol 20:522-31.

Sala F, Rigano MM, Barbante A, et al. 2003 Vaccine antigen production in transgenic plants: Strategies, gene constructs and perspectives. Vaccine 21:803-8.

Stewart PA, Knight AJ. 2005. Trends affecting the ise. Bananas that could cheaply and easily deliver vaccines to children throughout the tropics could be a wonderful invention. But there are downsides; it will be difficult to avoid food contamination and potential harmful effects to wildlife if pharmaceuticals are widely produced in food crops grown out of doors.

Finally, the pros and cons of alternative strategies to achieve the same goals should be assessed (O'Brien 2000). For example, could certain pharmaceutical crops reasonably be confined to greenhouses, caves or other enclosed facilities? Are there other possible routes to the inexpensive and efficient production of drugs that perhaps do not involve the transgenic manipulation of crop plants? The future course of this technology will require thoughtful input from ecologists, public health experts and medical researchers - as well as those who genetically engineer these crops in the first place.

M. Marvier is Associate Professor, Environmental Studies Institute and Department of Biology, Santa Clara University.

next generation of U.S. agricultural biotechnology: Politics, policy, and plant-made pharmaceuticals. Technol Forecast Soc 72:521-34.

Stewart PA, McLean W. 2004. Fear and hope over the third generation of agricultural biotechnology: Analysis of public response in the Federal Register. AgBioForum 7:133-41.

Union of Concerned Scientists. 2003. Pharm and Industrial Crops: The Next Wave of Agricultural Biotechnology. Cambridge, MA. www.ucsusa.org/ food_and_environment/genetic_engineering/ pharm-and-industrial-crops.html.

Union of Concerned Scientists. 2007. Pharma Crop Approvals in the United States. Cambridge, MA. http://go.ucsusa.org/food_and_environment/ pharm/ (accessed Feb. 18, 2007).

[USDA] US Department of Agriculture. 2005 Audit Report: Animal and Plant Health Inspection Service Controls Over Issuance of Genetically Engineered Organism Release Permits. Office of the Inspector General. Audit \#50601-8-Te, December.

[USDA APHIS] Animal and Plant Health Inspection Service. 2007. USDA Release Permits for Pharmaceuticals, Industrials, Value Added Proteins for Human Consumption, or for Phytoremediation Granted or Pending by APHIS. www.aphis.usda.gov/brs/ph_permits.html.

Vogel G. 2006. Tracing the transatlantic spread of GM rice. Science 313:1714.

Walmsley AM, Arntzen CJ. 2000. Plants for delivery of edible vaccines. Curr Opin Biotechnol 11:126-9.

Wisner R. 2005. The Economics of Pharmaceutical Crops: Potential Benefits and Risks for Farmers and Rural Communities. Union of Concerned Scientists, Cambridge, MA. www.ucsusa.org/food_and_ environment/genetic_engineering/ economics-of-pharmaceutical-crops.html. 